\title{
Motivators for Demotivators Affecting English Language Acquisition of Saudi Preparatory Year Program Students
}

\author{
Ayman Sabry Daif-Allah ${ }^{1,2}$ \& Abdulaziz Saleh Alsamani ${ }^{2}$ \\ ${ }^{1}$ Suez Canal University, Egypt \\ ${ }^{2}$ Qassim University, Saudi Arabia \\ Correspondence: Ayman Sabry Daif-Allah, Buraydah Community College, Qassim University, Saudi Arabia. \\ E-mail: sabryayman@hotmail.com
}

Received: September 15, 2013 Accepted: October 6, 2013 Online Published: December 5, 2013

doi:10.5539/elt.v76n1p128 URL: http://dx.doi.org/10.5539/elt.v7n1p128

\begin{abstract}
This study aims at investigating the demotivating factors that discourage Preparatory Year Program (PYP) students from learning the English language. It also proposes and tests the effectiveness of a set of academic and administrative approaches on enhancing English language acquisition of 102 Saudi PYP Students taking an EFL summer course in the Deanship of Educational Services, Qassim University. The quantitative and qualitative data were collected by means of questionnaire, analysis of test scores, classroom observation, teachers' feedback and informal interviews with students. The findings specified nine significant extrinsic demotivators affecting Saudi students' EFL learning where a set of practical strategies were implemented to remotivate students and help them learn English better. On top of these strategies came reduction of class size, weekly quizzes and extracurricular activities. The results of the research indicated that the proposed strategies were very successful in restoring PYP students' motivation, increasing the amount of their learning, developing teachers' promptness and establishing good rapport between students and teachers.
\end{abstract}

Keywords: motivation, remotivation, demotivation, teaching strategies, language

\section{Introduction}

Research on motivation in foreign language learning has emphasized the underlying reasons behind the involvement or noninvolvement of EFL learners in academic activities (Muftah \& Rafik-Galea, 2013). "Motivation," "remotivation" and "demotivation" are important factors that play a crucial role in academic study in general, and in the process of sustained English language acquisition in particular (Dörnyei, 2009). The word "motivation" has been defined as the intrinsic and external forces that account for the initiation, selection, and direction of behavior towards a goal (Babaee, 2012). It refers to the characteristics of learners "that initiates and maintains the learning process, or that leads to the avoidance or rejection of learning (Stern, 1983: 385)". It is, therefore, one of the key factors which determine the design and implementation of language instruction, and which influence the success or failure of learning a foreign or second language (Alamin \& Ahmed, 2013). Remotivation is a process of reinstating motivation through overcoming sources of demotivation, and enhancing those intrinsic and external factors that help stimulate learners' interest and enthusiasm to learn (Wong, 2011).

On the other hand, demotivation is regarded as specific external forces that reduce or diminish the motivational basis of a behavioral intention or an ongoing action (Goodluck, 2013). It refers to factors which act in opposition to motivation and diminish a student's drive to learn English and participate in learning activities (Alavinia, 2012; Ikeno, 2002). Falout and Maruyama (2009) believe that, whereas motivation spurs on learning for life, demotivation cuts learning short. Dörnyei and Ushioda (2011) have remarked that in addition to positive factors that encourage action, there are negative factors that have the opposite effect. They add that the darker side of motivation, de-motivation, has been found to play a crucial role in the learning process, yet it has been neglected as a research topic until fairly recently. Thus, a demotivated learner is someone who has lost his or her interest to study due to various sources of demotivation like experiencing failure, inappropriate teacher behavior, or the lack of consideration to learners' needs ( $\mathrm{Hu}, 2011)$.

\section{Context of the Problem}

Recent research results in Saudi Arabia (Daif-Allah, 2005; Al-Shammary, 1984) indicated that Saudi students at 
various levels of study are highly motivated to learn English. Most students study English in order to pass exams, get an EFL qualification, have better career prospects and understand English-speaking people and their way of life. The present researchers observed that quite a significant number of high school graduates in Saudi Arabia detest studying English although they recognize the need for having a good command of English given the current trend of increased globalization. It is common for students to lose interest immediately after starting an English course, resulting in poor performance. So, why do such learners lose their motivation to study the target language? This issue may be of interest not only to researchers but also to teachers. Those teachers who daily see their learners becoming increasingly demotivated in class may want to understand the possible reasons behind it. This may help them avoid becoming the cause of their demotivation.

A considerable amount of research has been conducted to investigate the nature and influence of motivation in piquing the interest of poorly motivated English learners (Pan \& Wu, 2013; Salem, 2006; Obeidat, 2005; Oxford \& Shearin, 1996). Other investigations have explored why learners lose interest in studying English (e.g., Alavinia, 2012; Hood, 2009; Sakai \& Kikuchi, 2009; Falout \& Maruyama, 2008; Trang \& Baldauf, 2007). Studies that advocate strategies to enhance intrinsic and external motivational components in language learners were carried out by Lai and Ting (2013), Alexenoamen (2009) and Williams and Burden (1997). However, none of these studies tackled both demotivators and motivators on the same sample. In addition, none of them was carried out in the Saudi context and more specifically with students attending the PYP - a mandatory one-year prerequisite for students who wish to enroll in Qassim University's various undergraduate programs. The main purpose of this program is to facilitate a smooth transition from Arabic as medium of instruction in secondary schools to English at college level. The present study sets out to fill this gap in research, by firstly investigating the external factors that discourage Saudi PYP students from learning English and secondly, testing the impact of a set of motivational strategies to enhance English language acquisition.

\section{Research Questions}

This study seeks to answer the following questions:

1) What are the factors that serve to demotivate PYP students in English language acquisition?

2) How can low proficient PYP students be remotivated to learn English?

3) What is the effect of introducing a set of motivators on the English language acquisition of PYP students?

\section{Hypotheses}

1) The suggested remotivating strategies will significantly reduce demotivators in PYP students.

2) The Statistics will show a significant improvement in the results that students achieve during the summer exam, compared with the in-term exam prior to that.

\section{Research Objectives}

This study aims to:

1) Identify the external factors that discourage Saudi PYP students in the English language classroom.

2) Introduce a set of practical strategies for creating a supportive learning environment for PYP learners.

3) Examine the impact of avoiding demotivators on PYP students' acquisition of English as a foreign language.

\section{Research Methodology}

\subsection{Participants}

In order to investigate the demotivating factors on Saudi PYP learners, 106 students were asked to complete a questionnaire about the factors they find discouraging. These students were repeating a summer EFL course at the Deanship of Educational Services, at Qassim University. The mean age of the respondents is 18 and the average mean score in their final college examination was $39.77 \%$. Arabic was both their first language as well as the language of instruction during their pre-university schooling.

\subsection{The Questionnaire}

The EFL demotivation questionnaire consisted of seventeen 5-point Likert type statements about demotivation. It was designed to measure five themes: Teachers' Competence and Teaching Styles (items 1-5),) Class Environment (items 6-8) Examination process (items 9-11), Lack of interest (Intrinsic Motivation) (Items 12-15), and Learning Contents and Materials (items 16-17). Most of the items in this section were inspired by students' written or oral complaints about learning conditions, and informal interviews with 25 PYP English language learners at Qassim University. Other items were derived and adapted from previous studies (Sakai \& Kikuchi, 
2009; Tsuchiya, 2006a). After constructing the questionnaire, it was piloted on 15 students to assess its level of reliability, and then it was submitted to a group of TEFL experts to estimate its validity. Cronbach's Alpha Coefficient was used to approximate internal consistency of items. The Alpha reliability estimate for the questionnaire was 0.699 , which is a reasonably acceptable estimate for an instrument of this kind.

\subsubsection{Questionnaire Results}

Data gleaned from the EFL demotivation questionnaire provided the answer to the first research question: "What are the demotivating factors that affect English language acquisition of PYP students?" The quantitative data that emerged from the students' responses are tabulated and analyzed statistically using frequency of responses, weighted percentages and rank order in Table 1 below.

Table 1. Descriptive statistics for PYP students questionnaire responses $(\mathrm{N}=106)$

\begin{tabular}{|c|c|c|c|c|c|c|c|}
\hline \multirow[t]{2}{*}{$\begin{array}{l}\text { How much is each of the following } \\
\text { statements true for you as a } \\
\text { demotivating factor? }\end{array}$} & True & $\begin{array}{l}\text { True to some } \\
\text { extent }\end{array}$ & $\begin{array}{l}\text { Neither true } \\
\text { nor untrue }\end{array}$ & $\begin{array}{l}\text { Mostly } \\
\text { untrue }\end{array}$ & $\begin{array}{l}\text { Not } \\
\text { true }\end{array}$ & \multirow[t]{2}{*}{$\begin{array}{l}\text { Weighted } \\
\text { average }\end{array}$} & \multirow[t]{2}{*}{$\begin{array}{l}\text { Rank } \\
\text { order }\end{array}$} \\
\hline & N. & N. & N. & N. & & & \\
\hline \multicolumn{8}{|c|}{ Teachers' Competence and Teaching Styles } \\
\hline $\begin{array}{l}\text { 1) Teachers' speed of teaching is } \\
\text { fast. }\end{array}$ & 72 & 23 & 3 & 2 & 6 & 4.5 & 4 \\
\hline $\begin{array}{l}\text { 2) Teachers give one-way } \\
\text { explanations too often. }\end{array}$ & 65 & 20 & 4 & 8 & 9 & 4.3 & 5 \\
\hline $\begin{array}{l}\text { 3) Teachers insult and ridicule } \\
\text { students' mistakes. }\end{array}$ & 5 & 4 & 6 & 18 & 73 & 2.3 & 10 \\
\hline $\begin{array}{l}\text { 4) Teachers give too much } \\
\text { homework and very little in-class } \\
\text { work. }\end{array}$ & 89 & 6 & 2 & 3 & 6 & 4.6 & 3 \\
\hline $\begin{array}{l}\text { 5) Teachers Embarrass students by } \\
\text { asking difficult questions or the } \\
\text { answers to which are not known. }\end{array}$ & & 28 & 6 & 33 & 39 & 2.8 & 6 \\
\hline \multicolumn{8}{|l|}{ Class Environment: } \\
\hline $\begin{array}{l}\text { 6) The number of students in } \\
\text { classes is large. }\end{array}$ & 92 & 12 & 0 & 2 & & 4.8 & 1 \\
\hline $\begin{array}{l}\text { 7) The frequent changing of } \\
\text { teaching staff is demotivating. }\end{array}$ & 84 & 7 & 0 & 3 & 12 & 4.5 & 4 \\
\hline $\begin{array}{l}\text { 8) The large number of examinees } \\
\text { creates an opportunity for students } \\
\text { to cheat. }\end{array}$ & 87 & 4 & 6 & 5 & 4 & 4.5 & 4 \\
\hline \multicolumn{8}{|l|}{ Examination process } \\
\hline $\begin{array}{l}\text { 9) Two mid-term exams require a } \\
\text { lot of preparation and therefore } \\
\text { interrupt regular classes. }\end{array}$ & 97 & 3 & 6 & 0 & 0 & 4.7 & 2 \\
\hline $\begin{array}{l}\text { 10) Students do not receive } \\
\text { corrective feedback for in-term } \\
\text { exams. }\end{array}$ & 91 & 8 & 7 & 0 & 0 & 4.7 & 2 \\
\hline $\begin{array}{l}\text { 11) Students are not adequately } \\
\text { prepared for the EFL exams. }\end{array}$ & 79 & 15 & 6 & 2 & 4 & 4.5 & 4 \\
\hline \multicolumn{8}{|l|}{ Lack of interest ( Intrinsic Motivation) } \\
\hline $\begin{array}{l}\text { 12) I am not interested in learning } \\
\text { English. }\end{array}$ & 15 & 6 & 5 & 10 & 70 & 2.6 & 7 \\
\hline $\begin{array}{l}\text { 13) I have no objective to be a } \\
\text { speaker of English. }\end{array}$ & 8 & 8 & 7 & 15 & 68 & 2.5 & 8 \\
\hline $\begin{array}{l}\text { 14) I am often compared with my } \\
\text { friends. }\end{array}$ & 2 & 9 & 4 & 25 & 66 & 2.4 & 9 \\
\hline
\end{tabular}




\begin{tabular}{|c|c|c|c|c|c|c|c|}
\hline $\begin{array}{l}\text { 15) I was confident in learning } \\
\text { English before I started learning it } \\
\text { in the PYP. }\end{array}$ & 7 & 7 & 4 & 19 & 69 & 2.5 & 8 \\
\hline \multicolumn{8}{|l|}{ Learning Contents and Materials : } \\
\hline $\begin{array}{l}\text { 16) Most of the lessons focus on } \\
\text { grammar. }\end{array}$ & 5 & 30 & 3 & 13 & 55 & 2.8 & 6 \\
\hline $\begin{array}{l}\text { 17) The English sentences in the } \\
\text { lessons are difficult to interpret. }\end{array}$ & 7 & 9 & 8 & 14 & 68 & 2.5 & 8 \\
\hline
\end{tabular}

The table above shows that the highest weighted average is 4.8 and the lowest is 2.3 . Accordingly, the cut-score point for the questionnaire items is (3.5). All the items with a weighted average higher than the criterion are regarded as significant demotivators for PYP learners in Qassim University. Three themes with nine external factors that significantly contributed to students' demotivation are listed in table 2 below.

Table 2. Descriptive statistics for the most significant motivating factors as seen in the low proficient PYP students $(\mathrm{N}=106)$

\begin{tabular}{|c|c|c|}
\hline The top nine demotivators that discourage PYP learners from learning English & Total True $\%$ & W.A \\
\hline \multicolumn{3}{|l|}{ A) Examination process: } \\
\hline Two mid-term exams require a lot of preparation and therefore interrupt regular classes. & 94.33 & 4.7 \\
\hline Students do not receive corrective feedback for in-term exams. & 93.39 & 4.7 \\
\hline Students are not adequately prepared for the EFL exams. & 89.62 & 4.5 \\
\hline \multicolumn{3}{|l|}{ B) Class Environment: } \\
\hline The number of students in classes is large. & 98.11 & 4.8 \\
\hline The frequent changing of teaching staff is demotivating. & 85.84 & 4.5 \\
\hline The large number of examinees creates an opportunity for students to cheat. & 85.84 & 4.5 \\
\hline \multicolumn{3}{|l|}{ C) Teachers' Competence and Teaching Styles: } \\
\hline Teachers give too much homework and very little in-class work. & 89.62 & 4.6 \\
\hline Teacher's speed of teaching is fast. & 89.62 & 4.5 \\
\hline Teachers give one-way explanations too often. & 80.18 & 4.3 \\
\hline
\end{tabular}

\subsection{The Treatment}

This study is targeted at the academic improvement of the weaker and more demotivated PYP learners who could not perform well in the regular term and lagged behind. Accepting this challenge and in an attempt to find an answer to the second research question "How can low proficient PYP students be remotivated to learn English?", the researchers suggested and implemented a set of motivating strategies, in response to the nine demotivators indicated in table 2, to activate intrinsic and external motivational components in PYP learners for the purpose of enhancing their English language acquisition. These are:

1) Reducing class size. When the PYP was started at Qassim University, there were 70 students per class. The overall pass rate of students for the first year was $18 \%$. These results were partly attributed to over-crowded classes, so the PYP administration decided to reduce the number of students per class to between 25 and 30, even though this was still higher than the desired number of 15 students per class.

Bearing in mind that $98.11 \%$ of PYP students were demotivated because of the large number of students per class, the researchers proposed a class size of fifteen students as a means of motivating the students. This allowed weaker PYP students who required special attention more time to get assistance from their teachers. It also helped the teachers in a number of ways. It made it possible for them to give demotivated PYP learners an opportunity to take part in extended practice to use the language in a meaningful way, it helped them manage their lessons effectively and give their students a sense of control with regard to classroom activities, to create a sense of community among their students, to develop learner-centered teaching, to understand their learners' 
needs and classroom participation styles, to establish effective student-student and student-teacher interaction, and it helped them promote effective learning through using a variety of teaching techniques such as whole-class teaching, individual work, group work, and pair work.

Since the seating of students had been a crucial element in the success or failure of lessons, the new class size allowed teachers to change the way students were seated in the classroom from rows to a semi circle. This simple change in the seating pattern made a big difference to group coherence and student satisfaction. The result was, classroom explanation turned into a two-way method rather than one-way and hence avoided another EFL demotivator, namely that "Teachers made one-way explanations too often as indicated by $80.18 \%$ of PYP students".

2) Administering weekly quizzes. A very significant factor underlying PYP students' demotivation was "lack of adequate preparation for the EFL exams, " as seen by $89.62 \%$. To find a solution to this serious problem, the researchers introduced weekly quizzes to familiarize the students with assessment patterns in the exams, to keep them studying, to provide them with opportunities to practice taking exams, and enhance their EFL acquisition. Compared to regular terms, where students get little preparation for exams, the summer term students were adequately prepared for all EFL exams since they took and practiced fifteen quizzes before the in-term exam and thirty quizzes before the final examination. This greatly helped the students towards their goal because it familiarized them with both the course material and the format of the examination.

3) Giving corrective feedback. Corrective feedback is another remotivating factor that helped increase the motivation of PYP learners to learn English. The researchers applied this strategy to support and show concern for PYP students who, for the first time, had the chance to find out what mistakes they had made and learn how to avoid making them in future quizzes or exams. There were teachers who thought that the purpose of assessing students is to measure their performance and that the ultimate aim of correction is to tell students their scores. Those teachers were informed that the ultimate goal of assessment is improving student performance, which is achieved by giving students corrective feedback. Teachers were instructed to give informative and encouraging feedback in a positive manner that increases the motivation of students and interest to learn. Teachers were also requested to discuss errors in general with the whole group ad to avoid embarrassing students in class, accept individual differences, create a friendly atmosphere, and have a sense of humor. This strategy was an immensely contributing factor to PYP students' success and increased their self confidence. In so doing, it was effective in overcoming demotivating factor that "Students do not receive corrective feedback for In-Term exams (93.39\%)".

4) Doing in-class work. The purpose of assigning homework is to allow students to practice what they learn in class and to accept some responsibility for their own learning. To encourage students to do their homework, the PYP administration assigned $10 \%$ of the total mark for completing homework. In regular terms, the researchers noticed that most of the students did not do their homework themselves since most of the answers were almost the same and written in a language above their level. Students were in the habit of using private tutors to do their homework on their behalf so that the students could get the full ten marks assigned for homework. As a result, the main aim of doing homework changed from application of knowledge to getting marks. This problem did not end there for $89.62 \%$ of PYP students indicated that they were demotivated to learn English because "Teachers give too much homework". As a result, the researchers introduced a system of in-class work, in which students took a two-hour period of doing in-class work every week, to ensure that students do their homework themselves for the sole purpose of developing language achievement and performance. In these classes, PYP students did the greater part of their homework themselves under the supervision of a professional teacher whose role was not to do the homework for students, but limited to providing help on how to do it. The introduction of in-class work sessions was very effective in avoiding the EFL demotivator for PYP students, namely "Teachers give too much homework and very little in-class work (89.62\%)".

5) Coordinating language skills. To ensure the proper implementation of the summer term study plan, three experienced teachers were selected to coordinate the three skills of listening, reading, and writing. The basic duty of each skill coordinator was to closely supervise the teaching of the course syllabus and in staying up to date on the progress of each teacher in covering the syllabus. Also, each skill coordinator arranged regular meetings every other week to pass on new information, to get feedback from teachers about students' progress and to discuss problems and suggest solutions. Collecting Weekly Course Progress Reports (WCPR) from teachers was another important task for the skill coordinator. The WCPR is a form that is filled out by all teachers at the end of each teaching week and submitted to the skill coordinator. In this form each teacher indicates how much work was covered that week, whether he is on syllabus or not, and to give reasons if he had fallen behind. This form was very important in helping the skill coordinator stay abreast of any problems the teachers experienced in covering the syllabus. The introduction of skill coordination with the aid of the WCPR was another effective 
strategy for avoiding an important demotivator concerning teachers' speed of teaching, namely "Teacher's speed of teaching is fast as seen by 89.62 of PYP students".

6) Instant payment for replacement. Teacher absenteeism was identified as another serious problem that required intervention with as many as six rotating substitute teachers covering classes every week. This problem resulted in incomplete courses, inconsistent teaching and poor class management. It also demotivated a large number of PYP students who couldn't tell who their skill teacher was. Teachers who covered for others did so unwillingly since they received no extra remuneration for doing so. For this reason, rather than actual instruction they preferred to occupy their time correcting homework with the students or doing activities that they knew the students would find entertaining. This was understandable for several reasons. First, they were assigned these extra classes mainly to keep students occupied. Second, they did so unprepared and on the spur of the moment. Third, in some cases they had to cover a skill they themselves did not teach.

For the duration of the summer program teachers are strongly discouraged from being absent as it could affect the whole program. In addition, they are paid the incentive of receiving double their salary for teaching over the holiday.

In their endeavor to find a solution to teacher absenteeism, the researchers introduced the "Substitute Teacher Payment" (STP) system in which a cash fine was used as both a discouragement and a reward. According to the STP system, an absent teacher would pay a cash fine to the teacher who covered for him. This procedure was an incentive for teachers to substitute for another and a penalty for being absent. The teacher who had to miss a class had to inform the administrator for the Summer Program with exact details as to what part of the syllabus was to be covered in his absence, including chapter number, page number, and activity number. If any homework had to be given or checked, that information also had to be included. Equipped with the exact details of the class to be covered and a financial incentive, the substitute teacher was motivated to do justice to his work.

The STP system was very effective in reducing teacher absenteism. Comparing the regular term with the subsequent summer program (which included 864 classes), teacher absenteeism was reduced from an average of five weekly absences and two hundred and forty missed classes, to only two absences and four missed classes. This procedure helped in reducing a major demotivating factor discouraging $85.84 \%$ of PYP students from studying English, namely that "the frequent changing of teaching staff is demotivating".

7) Eliminating cheating. Cheating was another source of discouragement for PYP students. Although most of the students are honest, yet fear of failure, high levels of stress, parental expectations, lack of preparation, and the pressure to achieve high grades might cause a few students to cheat out of desperation. Overcrowded examination rooms made it easier to cheat for those students who had made arrangements to do so prior to the exam. In the absence of a watchful invigilator their close physical proximity made it possible for some students to cheat using body language. Even if these attempts went by unnoticed by invigilators, the other students still noticed them. Cases of successful cheating that came out during marking or in reports to the dean made it clear that certain students were successful in their attempts to cheat. In response to this problem, the researchers set up a comfortable multi-level, multi-group examination environment that made cheating unattainable. The innovative seating arrangement and the limited number of examinees in each examination room were the key factors in the researcher's attempts to curb dishonesty during exams. Various measures were taken to achieve this.

a) The number of students per exam room was limited to 15 students. In addition they were seated next to students from another level or group.

b) Extra chairs were removed from the rooms to make it easy for even a single teacher to move about with ease and have all the students within full view.

c) Level one and level two students were mixed in each examination room.

d) Each student was allotted a seat bearing his name, group number, level and ID number.

e) Four different versions of each exam were created so that students of each level had different versions of the exam.

Wide-ranging measures were taken to ensure exams were fair and honest. This encouraged students to study hard and rely on their own efforts to achieve during evaluation. Accordingly, it avoided a basic learning demotivator, namely that "the large number of examinees creates an opportunity for students to cheat (85.84\%)".

\subsection{The Effect of Treatment}

In an attempt to answer the third research question, "What is the effect of introducing a set of motivators on PYP 
students' English language acquisition?" four ways were used to assess what the effect was of the above mentioned remotivating strategies on the achievement of students in English language acquisition. These are: test scores; classroom observation; teachers' feedback; and informal interviews with students.

\subsubsection{Test Scores}

To test the validity of the proposed remotivating strategies on PYP students' English language acquisition, it was important to consider students' results for the in-term \& final exams. The in-term exam results were indeed surprising and even the average students showed very encouraging results. The following table shows the in-term exam results for the subjects of the study:

Table 3. Midterm exam results for PYP students

\begin{tabular}{lllll}
\hline $\begin{array}{l}\text { Nr. of Exam } \\
\text { Takers }\end{array}$ & $\begin{array}{l}\text { Nr. of Students } \\
\text { Passed }\end{array}$ & $\begin{array}{l}\text { Nr. of Students } \\
\text { Failed }\end{array}$ & $\begin{array}{l}\text { \% of Failed } \\
\text { Students }\end{array}$ & $\begin{array}{l}\% \text { of Passed } \\
\text { Students }\end{array}$ \\
\hline 106 & 87 & 19 & 17.92 & 82.07 \\
\hline
\end{tabular}

These midterm results gave a boost to students who became more motivated and hence were encouraged to face the final exam. The following table shows the final exam results for the subjects of the study. As can be seen in the table, the total number of students went from 106 to 102 after four of them dropped out.

Table 4. Final exam results for PYP students

\begin{tabular}{lllll}
\hline $\begin{array}{l}\text { Nr. of Exam } \\
\text { Takers }\end{array}$ & $\begin{array}{l}\text { Nr. of Students } \\
\text { Passed }\end{array}$ & $\begin{array}{l}\text { Nr. of Students } \\
\text { Failed }\end{array}$ & $\begin{array}{l}\text { \% of failed } \\
\text { students }\end{array}$ & $\begin{array}{l}\text { \% of Passed } \\
\text { students }\end{array}$ \\
\hline 102 & 86 & 16 & 15.68 & 84.32 \\
\hline
\end{tabular}

For the first time since the commencement of the PYP, students achieved a success rate of $84.32 \%$. This success shows that teachers did so well that the students were able to respond to the innovative remotivating factors and the new study scheme. The students' scores in the final exam that summer were also compared with their most recent exam in the previous spring term as shown in the following figure.

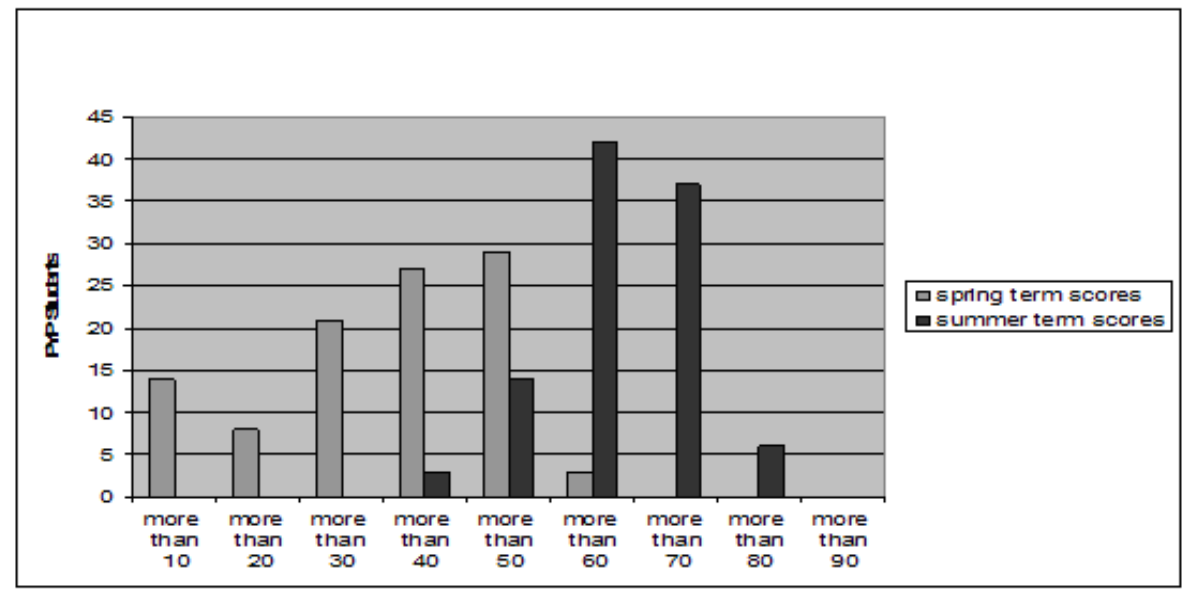

Figure 1. PYP students' scores in the summer and spring terms

The data in the above figure show the effect of the proposed strategies in increasing the level of motivation in students to learn English. While the students' scores in the spring exam were below $60 \%$, the majority of the same sample $(84.32 \%)$ got $60 \%$ and above. Also, the mean scores for the same sample rose from $39.77 \%$ in the spring term exam to $67.32 \%$ in the summer term exam. The following figure shows the improvement in students' language achievement in the summer term compared with that of the spring term. 


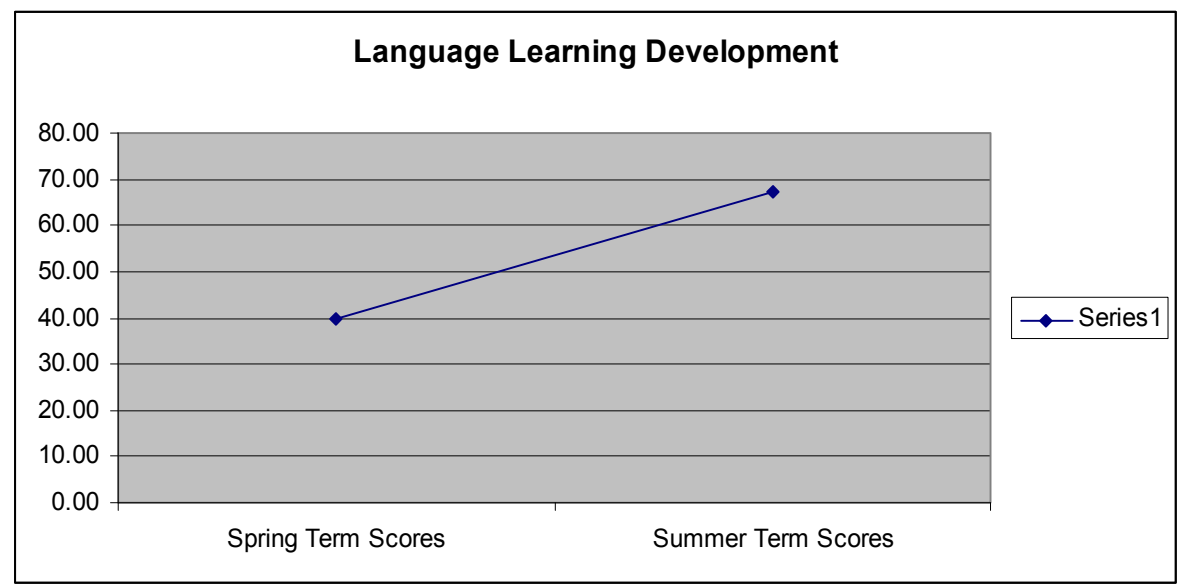

Figure 2. Achievement in language learning

In addition, a statistical analysis of independent-samples T-test was carried out to assess the change in the English language achievement of the students by comparing summer term and spring term test data. The results are presented in Table 3 below.

Table 5. T-tests assessing change in students' English language achievement

\begin{tabular}{lllllllll}
\hline Administration & $\mathrm{N}$ & Mean & St Dev & $\mathrm{T}$ & $\mathrm{DF}$ & Tabulated (t) & Sig. (2-tailed) & Decision \\
\hline Spring Exam & 102 & 39.77 & 14.97 & & & & & Statistically \\
Summer Exam & 102 & 67.33 & 8.32 & -15.31 & 101 & 1.984 & 0.000 & Extremely \\
Difference & 102 & -27.55 & 18.17 & & & & & Significant \\
Differences \\
\hline
\end{tabular}

The data in the table above shows significant statistical differences between the mean scores of the students in the summer and spring exams in favor of the summer exam. Obviously, the absolute value of the calculated't' $(-15.31)$ is bigger than the tabulated one (1.984) at the degree of freedom (101) and this is statistically extremely significant at 0.05 level.

\subsubsection{Classroom Observation}

Classroom observation focused on four aspects: teacher and student punctuality, the motivating role of the teachers, student-teacher rapport, and class size. Comments on classroom observation were noted down by the researchers and the skill coordinators. Punctuality was found to be a key feature, characterizing the proposed remotivation strategies. The researchers observed that teachers and students had become more punctual than before. It was punctuality that controlled demotivators such as the frequent changing of teachers, the speed of teaching, and cheating. These results confirm previous research results by Sucaromana (2013), Khorshidi and Nimchahi (2013) and Hick (2010) who found that teachers play a crucial role in creating motivating learning environments by employing a number of conscious and proactive motivational strategies and that the teacher's role and feedback were very helpful in motivating students in class. A class size of fifteen students was found to be the most advantageous for PYP students because it helped in establishing a good rapport among students and between students and teachers. It also increased the time a teacher is able to devote to each individual student, especially those who have learning difficulties. It also enabled PYP teachers to vary their teaching practices to suit students' learning styles. These findings were emphasized by (Ning, 2011; Betts \& Shkolnik, 1999) who noted that teachers in smaller classes give extra attention to students who are falling behind since they spend less time on discipline. In addition, Hattie (2005) found that a reduced class size of 15 is one of the means of enhancing the outcomes students achieve and of creating the optimal conditions to maximize the probability that those outcomes can be realized in a cost-, time- and effective manner.

\subsubsection{Teacher Feedback}

Teacher feedback on the program was positive and inspiring. Some of their comments include: "It was for the 
first time the staff and the students really felt the difference between the previous and this summer term". "Organization, professional discipline and seriousness of purpose gave a new direction to the summer studies". "The teaching staff was kept in high spirits and everybody took up his assignments seriously". "Inspired by the enthusiasm, dedication and keen interests, teachers worked diligently and efficiently. They burnt midnight oil in making the summer program exemplary and a model to be followed in future". Teachers also remarked that the examination strategy was a highlight in the summer term and that the healthy teaching/learning environment was the decisive factors for the success of this program.

\subsubsection{Student Feedback}

Feedback from students show the positive impact of the remotivating strategies had on their performance. Forty students were informally interviewed and the data gleaned are quoted in their own words below:

"We felt, for the first time, being recognized as important individuals". "The friendly student- teacher rapport reduced our tension". "The relaxed learning condition developed our attitudes towards school in general and learning in particular". "The Student Council helped us to express our needs and to come close to teachers". "We started to love school and we have become more interested in learning English". Students also explained that they unanimously favored the corrective feedback, the weekly quizzes, and the in-class work. They also liked the new seating arrangements that allowed them to work in pairs and small groups.

\section{Conclusions and Implications}

It goes without saying that demotivation, the loss of motivation due to particular circumstances, is a very significant language problem that should concern educationists and be specifically addressed in FL learning. It is a complex and serious obstacle to learning that needs to be investigated and faced so that the whole teaching process goes smoothly and efficiently. For this reason, the purpose of this paper was primarily to identify PYP students' EFL demotivators and suggest and test solutions for them. Data gleaned from the analysis of test scores showed the proposed academic strategies had a significant positive statistical impact on enhancing the EFL learning of PYP students. In terms of classroom atmosphere, the data showed a great improvement in the punctuality and classroom performance of the teacher. The introduction of in-class work sessions was also effective in developing learner autonomy since the students had to do the greater part of their homework themselves. In addition, a class size of fifteen students or less had a positive effect on the learning outcomes of the PYP students. All in all, the strategies proposed in this study could provide the appropriate teaching/learning conditions for the seeds of motivation to grow and mature in students.

As can be seen, educationists and policy makers need to work together to offer learners a healthy and dynamic learning environment, free from demotivating factors, and rich in meaningful student-teacher interaction in order to meet the goals of teaching English to all PYP learners. Teachers, on the other hand, should not only focus on transferring cognitive information, but also on showing a positive attitude and motivation towards teaching, and be role models for their learners.

\section{Suggestions for Further Research}

Based on the results, conclusions and implications of the present study, further research in the area under investigation is necessary. This may include:

1) Investigation of the demotivation phenomenon at different levels of education considering age and gender related variables.

2) Identifying additional demotivating factors that might have been addressed in the present study.

3) Collecting information on demotivating/ remotivating experiences from high proficient learners in various learning contexts.

\section{Limitations}

The results of the present study cannot be fully attributed to the proposed motivating strategies alone since the subjects of the study were repeat students and had studied the EFL courses before. Therefore, I hope for more research in the future to study the effect of the proposed remotivating strategies on developing English language learning in borderline students who have not studied the PYP English course before.

\section{References}

Alamin, A., \& Ahmed, S. (2013). Towards the Development of Communicative Language Approach for Adult EFL Students of the Community College, Taif University, KSA. English Language Teaching, 6(1), 20-27.

Alavinia, P. (2012). A Probe into the Main Demotivating Factors among Iranian EFL Learners. English 
Language Teaching, 5(6), 9-35.

Arai, K. (2004). What 'demotivates' language learners? Qualitative study on demotivational factors and learners' reactions. Bulletin of Toyo Gakuen University, 12, 39-47.

Babaee, N. (2012). Motivation in Learning English as a Second Language: A Literature Review. Canadian Journal for New Scholars in Education, 4(1), 1-7.

Betts, J. R., \& Shkolnik, J. L. (1999). The behavioral effects of variations in class size: The case of math teachers. Educational Evaluation and Policy Analysis, 21, 193-215.

Daif-Allah, A. (2005). An exploration of Saudi students' integrative and instrumental motivation for learning English as a foreign language. Occasional Papers, CEDELT, Ain Shams University, Egypt, 39, 57-96.

Dörnyei, Z., \& Ushioda, E. (2011). Teaching and researching motivation (2nd ed.). Harlow: Pearson Education Limited.

Dörnyei, Z. (2009). The L2 Motivational Self System. In Z. Dörnyei, \& E. Ushioda (Eds.), Motivation, Language Identity and the L2 Self (pp. 9-42). Bristol: Multilingual Matters.

Falout, J., \& Maruyama, M. (2008). A Comparative Study of Proficiency and Learner Demotivation. The Language Teacher, 28(8), 3-9.

Falout, J., Elwood, J., \& Hood, M. (2009). Demotivation: Affective states and learning outcomes. System, 37(3), 403-417.

Goodluck, H. (2013). Language Acquisition. Somerset, New Jersey: Wiley-Blackwell.

Hattie, J. (2005). The paradox of reducing class size and improving learning outcomes. International Journal of Educational Research, 43(6), 387-425.

Hick, M. (2010). Student Motivation: Inspiring the Future-Self Improvement. On-line Articles for the English Teaching Community. Retrieved June 27, 2013, from http://www.self-motivation-resources.com/info/Motivation/Student-motivation.html

Hu, R. (2011). The Relationship between Demotivation and EFL Learners' English Language Proficiency. English Language Teaching, 4(4), 88-96.

Ikeno, O. (2002). Motivating and demotivating factors in foreign language learning: A preliminary investigation. Ehime University Journal of English Education Research, 2, 1-19.

Khorshidi, H., \& Nimchahi, A. (2013). Motivation and Interlanguage Pragmatics in Iranian English Language Learners. English Language Teaching, 6(6), 86-96.

Lai, H., \& Ting, K. (2013). English Language Learners' Perceptions of Motivational Changes. English Language Teaching, 6(8), 10-20.

Muftah, M., \& Rafik-Galea, S. (2013). Language Learning Motivation among Malaysian Pre-University Students. English Language Teaching, 6(3), 92-103.

Ning, H. (2011). Adapting cooperative learning in tertiary ELT. ELT Journal, 65(1), 60-70.

Obeidat, M. (2005). Attitudes and Motivation in Second Language Learning. Journal of the Faculty of Education, UAEU, 18(22), 1-17. Retrieved October 2, 2010, from http://www.fedu.uaeu.ac.ae/Journal/PDF22/issue22-artical6.pdf

Oxford, R., \& Shearin, J. (1994). Language Learning Motivation: Expanding the Theoretical Framework. Modern Language Journal, 78, 12-28.

Pan, C., \& Wu, H. (2013). The Cooperative Learning Effects on English Reading Comprehension and Learning Motivation of EFL Freshmen. English Language Teaching, 6(5), 13-27.

Sakai, H., \& Kikuchi, K. (2009). An analysis of demotivators in the EFL classroom. System, 37, 57-69.

Salem, N. (2006). The Role of Motivation, Gender, and Language Learning Strategies in EFL Proficiency. (Unpublished MA thesis, Department of Education, the Faculty of Arts and Sciences, the American University of Beirut).

Sucaromana, U. (2013). The Effects of Blended Learning on the Intrinsic Motivation of Thai EFL Students. English Language Teaching, 6(5), 141-147.

Trang, T., \& Baldauf, R. (2007). Demotivation: Understanding Resistance to English Language Learning - The 
Case of Vietnamese Students. The Journal of Asia TEFL, 4(1), 79-105.

Tsuchiya, M. (2006a). Factors in demotivation of lower proficiency English learners at college. The Kyushu Academic Society of English Language Education (KASELE), 34, 87-96.

Wong, Y. M. (2011). A study of instrumental and intergrative motivations as factors influencing UTAR third year Chinese undergraduates in learning ESL. (Doctoral dissertation, UTAR).

\section{Copyrights}

Copyright for this article is retained by the author(s), with first publication rights granted to the journal.

This is an open-access article distributed under the terms and conditions of the Creative Commons Attribution license (http://creativecommons.org/licenses/by/3.0/). 